\title{
Cooperatives and the State: The Case of Ontario
}

\author{
Jen Heneberry \& Rachel Laforest
}

Queen's University

\begin{abstract}
In the early 2000s, the cooperative movement in Ontario came together in order to lobby its provincial government for active cooperative development support programs. Momentum was building for these types of programs. Already, many provincial governments had implemented active support programs in their jurisdiction. Despite having one of the largest cooperative sectors in Canada, Ontario was lagging behind. This article assesses the progress of the efforts of the Ontario cooperative movement to date. It details how the Ontario cooperative movement developed a sectoral identity for itself and framed its objectives in an effort to strengthen its relationship with the Ontario government.

\section{RÉSUMÉ}

Le mouvement coopératif en Ontario s'est rassemblé au début des années 2000 afin de faire pression sur le gouvernement provincial pour qu'il développe des programmes de soutient actif pour coopératives. Déjà plusieurs gouvernements provinciaux avaient mis en place de telles politiques. L'Ontario tardait malgré le fait qu'il avait un des plus grands secteurs coopératifs au Canada. Cet article examine le progrès qu'a connu le mouvement coopératif en Ontario dans ses efforts. II décrit comment le mouvement coopératif a construit une identité sectorielle autour de laquelle il a pu ancrer ses demandes auprès du gouvernement ontarien.
\end{abstract}

\section{Keywords / Mots clés}

Cooperative sector; Advocacy; Ontario politics / Mouvement coopératif; Action sociale; Politiques ontariennes

\section{INTRODUCTION}

One interesting development in the policy realm over the past decades has been the growing interdependence between governments, of all orders, and third parties such as voluntary sector and private sector organizations. This interdependence has necessitated the development of new tools and instruments of governance (Howlett, 2000; Salamon, 2002). Most significantly, to be effective in this context, governments have to learn how to steer complex networks of actors (Peters, 2001; Stoker, 1998). This involves a new structuring of relationships (Newman, 2001; Rhodes, 2000). At its core, broad whole-of-government strategies and macro frameworks are 


\section{Heneberry and Laforest (2011)}

needed to ensure the development of sustainable sectoral relationships. These new and enhanced strategies, in turn, require new mechanisms for communication and collaboration. What makes these tools so significant is that they involve new forms of organizational relationships.

The development of such macro scale relationships with the "voluntary sector," "nonprofit sector," and "social economy" is relatively well documented (Casey \& Dalton, 2006; Elson, 2006; Phillips, 2003; Toftisova, 2005). An important process in the development of these macro relationships is the way that organizations represent themselves to the state. To be effective, they have had to secure group representation before the state and within key bureaucratic agencies (Laforest \& Phillips, 2001). Whether under the name of the "voluntary sector," the "social economy," or the "third sector," sectoral actors have been very successful over the past decades at gaining attention and support from their respective governments in the form of agreements that recognize the unique role of nonprofits and voluntary organizations and strengthen the collaborative relationships between their sector and government (Casey, Dalton, Melville, \& Onyx, 2010).

The process however, has not always been straightforward. It requires the coming together of organizations from a diversity of backgrounds and policy fields to define and frame their common interests on a sectoral scale. The outcomes of these struggles have important consequences for the types of demands being made to the state. The politics behind relationship building initiatives matter.

One area that has been given much less attention in the literature on macro relationship building is that of the strengthening of the relationship between governments and the cooperative sector. In fact, other than a couple of seminal pieces in the 1980s, not much has been written on the Canadian cooperative sector ${ }^{1}$ in the academic literature; even less so at the provincial level (Laycock, 1987; MacPherson, 1979; Quarter, 1992). Yet, over the past decade, cooperative organizations across Canada have also been lobbying and collaborating with their respective provincial governments in order to strengthen their relationships, some quite successfully, others less so (Loxley \& Simpson, 2008).

This article looks at the case of cooperatives in Ontario. Despite having one of the largest cooperative sectors ${ }^{2}$, second only to Québec (Rural and Co-operatives Secretariat, 2010), it is one of the few provinces that has not been successful at lobbying its provincial government for active development programs. Yet the Ontario cooperative movement embarked on some important mobilization efforts in the early 2000s to ensure a strong sectoral presence in its interactions with the provincial government (Guy \& Heneberry, 2009). This article explores some of the challenges this movement faced.

The objectives of this article are two-fold. From a theoretical standpoint, it is important to illustrate lessons learned not only from successful cases of relationship building initiatives, as have been done in the past, but also from less successful initiatives. This will enable us to identify some of the barriers and challenges experienced in Ontario, relative to other provinces. From a practical standpoint, it is critical for the sustainability of the cooperative movement as a whole to be able to document the struggles and the progress of cooperatives in a variety of settings. The lack of existing research on the history of the cooperative movement in Ontario since the 1990s really highlights the importance of documenting this important transition period for the Ontario cooperative movement. To analyze this period of engagement and activism for the movement, we examined official documents, which included speeches, official policy statements, and websites of leading organizations in the cooperative sector and Ministries working with cooperatives (Guy \& Heneberry, 2009). This enabled us to collect background information and trace the history of the cooperative movement in Ontario. The bulk of the analysis is based on 14 interviews conducted in 2010 with leaders in the cooperative movement as well as 


\section{Heneberry and Laforest (2011)}

elected officials and civil servants who were directly engaged in the lobbying efforts on behalf of the cooperative movement.

The cooperative organizations in this sample were selected because of their direct involvement in the advocacy movement and in building the profile of the cooperative sector with the Ontario government ${ }^{3}$. Given that very little research currently exists on the cooperative sector in Ontario, we used qualitative interviews as the primary strategy for data collection, in conjunction with document analysis. Using open-ended interviews, we were able to reconstruct a timeline and the strategic considerations of the cooperative organizations involved in the advocacy efforts. These interviews also enabled us to gain a better understanding of the development of the movement's efforts and the challenges it has faced in achieving its goals. In addition, public officials from the Financial Services Commission of Ontario-the main government body with responsibility for cooperatives-as well as two members of the Ontario Provincial Parliament were interviewed for this research because they had been involved in the cooperative movement's initiatives to build the profile of the sector. They had observed first hand the dynamics between the cooperative movement and the Ontario government. These interviews were used mainly for the purpose of describing the policy setting and identifying the key players.

The article proceeds in three parts. First, we examine various examples of strong sectoral relationships between provincial governments and their respective cooperative sectors. We identify some of the key elements necessary to develop these sectoral relationships in order to have a basis from which to assess the Ontario case. The second part of the article examines the Ontario case in more depth. We set the historical context for understanding how the cooperative sector is structured and how these structures have evolved under the new governance process. The analysis recounts the strategic decisions made by cooperative movement representatives in an effort to capture their reading of the political environment in which they found themselves. The final part of the article draws some lessons from the Ontario case for other cooperative movements working in economic or social contexts that are similar to that of Ontario's. The analysis provides an opportunity to identify other strategies or directions that the movement might consider in continuing its efforts toward securing active cooperative development programs.

\section{COOPERATIVES AND PROVINCIAL GOVERNMENTS}

Since the late 1990s, cooperative organizations across Canada have been lobbying for their provincial governments to adopt supportive policies that promote the development of the cooperative sector (Fairbairn, 2000a, 2000b; Loxley \& Simpson, 2008). Although support programs for enterprises and different types of movements originate with both the federal and provincial governments, legislation governing cooperatives and the regulation of cooperatives is handled almost entirely at the provincial level (Rural and Co-operatives Secretariat, 2010; Ontario Co-operative Association, 2010). ${ }^{4}$ Hence, the provincial arena is an important one for the cooperative movement. Provincial cooperative movements share the common objective of wanting public policies and programs that are advantageous to the development of the co-op movement. However, how their demands materialize into actual policies varies across jurisdictions, depending on their ability to engage with their respective provincial government and how the movement navigates the political waters. Not surprisingly, then, we can observe a range of active cooperative development supports that exist in provinces across the country. Table 1 provides a breakdown of the different government functions and levels of support that exist for the cooperative movement in each of the ten provinces and three territories. 


\section{Heneberry and Laforest (2011)}

\section{Table 1: Provincial Government Support for the cooperative sector}

\begin{tabular}{|c|c|c|c|c|c|c|c|c|}
\hline \multirow[t]{2}{*}{ Prov. + Pop. } & \multicolumn{4}{|c|}{ Sector Profile } & \multicolumn{4}{|c|}{ Government Representation } \\
\hline & $\begin{array}{l}\text { \# of } \\
\text { Co-ops }\end{array}$ & $\begin{array}{l}\text { \# of } \\
\text { Members }\end{array}$ & $\begin{array}{l}\text { \#Working } \\
\text { in Sector }\end{array}$ & $\begin{array}{l}\text { Sales/Assets } \\
\text { (billions) }\end{array}$ & Department & Legislation & Budget & No. of Staff \\
\hline $\begin{array}{l}\text { Quebec } \\
7,700,800\end{array}$ & 3,300 & $\begin{array}{l}8.8 \\
\text { million }\end{array}$ & 88,000 & $\$ 160$ & $\begin{array}{l}\text { Ministry of Economic Development, Innovation } \\
\text { \& Exports: Direction des coopératives } \\
\text { Dept. of Finance - Regulation }\end{array}$ & $\begin{array}{l}\text { Cooperatives } \\
\text { Act }\end{array}$ & $\begin{array}{l}\$ 5.4 \text { million (\$1 million towards wages }+\$ 80,000 \\
\text { for additional operational costs }+\$ 4.3 \text { million co-op } \\
\text { develop. fund) }\end{array}$ & $\begin{array}{l}17 \text { in total: } \\
1 E D+5 \text { Staff }\end{array}$ \\
\hline $\begin{array}{l}\text { Ontario } \\
12,803,900\end{array}$ & 1,300 & $\begin{array}{l}1.4 \\
\text { million }\end{array}$ & 15,500 & $\$ 30$ & $\begin{array}{l}\text { Ministry of Finance: Financial Services } \\
\text { Commission of Ontario (FSCO) - Regulation }\end{array}$ & $\begin{array}{l}\text { Co-operative } \\
\text { Corporations } \\
\text { Act }\end{array}$ & $\begin{array}{l}\text { No budgetary provisions specific to co-operatives, as } \\
\text { work FSc0 staff do is driven by issues in the co-op sector } \\
\text { at a given time, and therefore varies- - e.g., 2007/2008 } \\
\text { expenditures relative to c0-ops was approx. } \$ 262,000\end{array}$ & $\begin{array}{l}2.3 \mathrm{FT} \\
\text { (assoc. with co-ops only) }\end{array}$ \\
\hline $\begin{array}{l}\text { Saskatchewan } \\
996,900\end{array}$ & 1,163 & 900,000 & 15,000 & $\$ 7$ & $\begin{array}{l}\text { Ministry of Enterprise and Innovation } \\
\text { Ministry of Justice- Regulation }\end{array}$ & $\begin{array}{l}\text { Co-operatives } \\
\text { Act }\end{array}$ & $\$ 684,000$ & $\begin{array}{l}1 \text { program manager plus } 6 \text { regional } \\
\text { development co-ordinators }\end{array}$ \\
\hline $\begin{array}{l}\text { Alberta } \\
3,474,000\end{array}$ & 754 & $\begin{array}{l}1.6 \\
\text { million }\end{array}$ & $\begin{array}{l}11,375 \\
\text { non-fnancial } \\
\text { sector only }\end{array}$ & $\$ 33.5$ & $\begin{array}{l}\text { Alberta Agriculture \& Food: Rural Utilities Division } \\
\text { Service Alberta - Regulation } \\
\text { Credit Union Deposit Corporation }\end{array}$ & Cooperatives Act & $\begin{array}{l}\text { No budgetary provisions - part of Ministry's overall } \\
\text { admin. expenses } \\
\text { n/a; } \$ 6.9 \text { million }\end{array}$ & $\begin{array}{l}12 \mathrm{FT} \text { (perform some } \\
\text { non-co-op functions) } \\
\text { 1/2 FT position for co-ops; } \mathrm{n} / \mathrm{a}\end{array}$ \\
\hline $\begin{array}{l}B C \\
4,380,300\end{array}$ & 635 & $\begin{array}{l}1.8 \\
\text { million }\end{array}$ & 13,000 & $\$ 20$ & $\begin{array}{l}\text { Ministry of Finance - Corporate Registrar - } \\
\text { Regulation }\end{array}$ & $\begin{array}{l}\text { Co-operative } \\
\text { Association Act }\end{array}$ & $n / a$ & n/a \\
\hline $\begin{array}{l}\text { Manitoba } \\
1,186,700\end{array}$ & 412 & 800,000 & 4,272 & $\$ 10$ & $\begin{array}{l}\text { Dept. of Agriculture, Food \& Rural Development } \\
\text { (MAFRI) - Co-operative Development Services } \\
\text { Dept. of Finance- Regulation }\end{array}$ & $\begin{array}{l}\text { Cooperatives } \\
\text { Act }\end{array}$ & $\$ 250,000$ & $\begin{array}{l}\text { 3 FT "Co-op Development } \\
\text { Specialists"; } 1 \text { PT (Deputy Registrar) } \\
\text { \&1 PT (Admin. support) }\end{array}$ \\
\hline $\begin{array}{l}\text { Nova Scotia } \\
934,100\end{array}$ & 400 & 308,000 & 7,000 & $\$ 5.1$ & $\begin{array}{l}\text { Service Nova Scotia \& Municipal Relations - } \\
\text { Co-operatives Branch - Regulation; NS Economic \& Rural } \\
\text { Development; NS Department of Community Services; } \\
\text { Nova Scotia Business Inc;; Nova Scotia Department of Fi- } \\
\text { nance; Nova Scotia Securities Commission; NS Depart- } \\
\text { ment of Environment \& Labour; Innovacorp }\end{array}$ & $\begin{array}{l}\text { Co-operatives } \\
\text { Act }\end{array}$ & $\begin{array}{l}n / a \\
\$ 100,000 \text { (contribution to NSCC) } \\
\$ 100,000 \text { (contribution to NSCC) }\end{array}$ & 1FT + 3PT regional \\
\hline $\begin{array}{l}\text { New Brunswick } \\
749,800\end{array}$ & 297 & 200,000 & 7,000 & $\$ 2.27$ & Dept. of Justice - Regulation & $\begin{array}{l}\text { Co-operative } \\
\text { Associations Act }\end{array}$ & No budgetary provisions & $\begin{array}{l}\text { 2FT-Registrar and Inspector } \\
\text { (not FT co-ops) }\end{array}$ \\
\hline $\begin{array}{l}\text { P.E.I } \\
138,600\end{array}$ & 114 & 87,267 & 750 & $\begin{array}{l}\$ 696 \\
\text { million }\end{array}$ & Dept. of the Solicitor General - Regulation & $\begin{array}{l}\text { Co-operative } \\
\text { Associations Act }\end{array}$ & 0 & $\begin{array}{l}\text { 1FT, 1FT assistant } \\
\text { (Not dedicated to co-ops) }\end{array}$ \\
\hline $\begin{array}{l}\text { Newfoundland } \\
\text { \& Labrador } \\
506,300\end{array}$ & 95 & 57,000 & 1,400 & $\$ 132$ million & $\begin{array}{l}\text { Dept. of Innovation, Trade \& Rural Development } \\
\text { Regional Co-op Developers Network (RDN); } \\
\text { Regional Developers Board; } \\
\text { Dept. of Government Services \& Lands - Regulation; } \\
\text { Dept. of Natural Resources }\end{array}$ & $\begin{array}{l}\text { Co-operatives } \\
\text { Act }\end{array}$ & $\$ 120,000$ & $\begin{array}{l}10 \text { (devote PT to co-op work) } \\
1 \text { PT (co-op registrar) }\end{array}$ \\
\hline $\begin{array}{l}\text { Nunavut } \\
31,100\end{array}$ & 23 & 13,011 & 1,371 & $\$ 84$ million & Dept. of Economic Development \& Transportation & $\begin{array}{l}\text { Co-operative } \\
\text { Associations Act }\end{array}$ & $n / a$ & n/a \\
\hline $\begin{array}{l}\text { NWT } \\
42,600\end{array}$ & 13 & 3,668 & 297 & $\$ 51$ million & Dept. of Industry, Tourism \& Development & $\begin{array}{l}\text { Co-operative } \\
\text { Associations Act }\end{array}$ & n/a & n/a \\
\hline $\begin{array}{l}\text { Yukon } \\
31,000\end{array}$ & 7 & n/a & $n / a$ & $n / a$ & $\begin{array}{l}\text { Government of Yukon Community Services- } \\
\text { Registrar of Co-operative Associations }\end{array}$ & $\begin{array}{l}\text { Co-operative } \\
\text { Associations Act }\end{array}$ & $n / a$ & $\mathrm{n} / \mathrm{a}$ \\
\hline
\end{tabular}

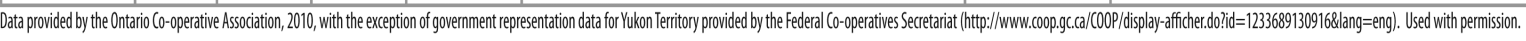




\section{Heneberry and Laforest (2011)}

While all provincial governments devote resources to their regulatory function, some have developed more extensive supports for cooperative organizations, such as funding programs, service delivery partnerships, or financial incentives (Fairbairn, 2000a, 2000b). In Nova Scotia, Newfoundland and Labrador, and Manitoba, multiple departments fund the development and growth of the cooperative organizations and enterprises. Newfoundland and Labrador, Manitoba, Saskatchewan, and Québec, for their part, have each entered into agreements with their respective cooperative sector in order to support the development of the cooperatives. Québec, for example, which has the largest provincial cooperative movement, ${ }^{5}$ adopted the Politique de Développement des Coopératives in December 2003 (Government of Québec, 2003) and signed a robust and wide-ranging agreement with the cooperative sector in July 2007 called the Entente de partenariat relativement au développement des coopératives. It also launched an annual $\$ 4.5$ million dollar fund to support cooperatives (Ministère du Développement économique, de l'Innovation et de l'Exportation, 2010).

The commonality in all of these cases is that these initiatives are tied to a broad macro framework approach to the respective relationships (Favreau, 2006; Loxley \& Simpson, 2008). This is a key feature of new governance approaches (Agranoff, 2006; Bryson, Crosby, \& Stone, 2006). These provincial governments have recognized cooperatives as important economic and social development tools (Fairbairn, 2000a, 2000b). In Manitoba, for example, the NDP government's Community Economic Development (CED) policy adopted in 1997 led to capacity building initiatives in the cooperative sector (Loxley \& Simpson, 2008). This broad macro recognition of the contribution of cooperatives to the province's development has important consequences on the processes of representation and legitimization of cooperatives. The vision structures, to a certain extent, the forms of interaction between the actors by directly affecting the terms of access to policymaking and the routes to political representation (Phillips, 2009; Laforest, 2011).

In fact, the provincial governments that have adopted a broad macro approach to their relationship with their cooperative sector have all instituted a co-ordinating body within government that plays a supportive and proactive role toward the cooperative sector. In Québec, for example, the Ministry of Economic Development, Innovation, and Exports houses a unit responsible for cooperative development. In Saskatchewan, the Ministry of Enterprise and Innovation is the main interlocutor with the cooperative sector; whereas in Newfoundland and Labrador it is the Department of Innovation, Trade, and Rural Development. In Manitoba, a Community Economic Development Committee was created within cabinet itself; whereas Saskatchewan established a Cooperative Advisory Council to facilitate the exchanges between the cooperative sector and the Ministry of Enterprise and Innovation, formerly the Ministry of Regional Economic and Co-operative Development. These bodies all act as identifiable focal points within government for the sector and have also helped to break down silos between Ministries (Kostyra, 2006; Smith, 2010). This institutionalized access has given cooperatives privileged access to the state in order to voice their needs and it has raised their profile within government. It has translated into a multi-faceted approach to supporting the sector that goes beyond legislation to providing institutional and financial support (Loxley \& Simpson, 2008). Not surprisingly then, we can observe in Table 1 that there are more staff dedicated to cooperative development within those provinces than in others. These examples signal that placing the responsibility for cooperative development within a clearly identified body can be beneficial to the cooperative movement (Fairbairn, 2000a, 2000b).

Perhaps more importantly, however, all of these cases illustrate the importance of political pressure and of mobilizing on behalf of the cooperative movement. An important process is the way that cooperatives represent themselves to the state. In Québec, the cooperative movement has a long history of mobilizing and engaging the state in policy. The movement framed their economic, social, and political contribution as one that is a vital part of the collective project of society (Laforest, 2007). Cooperatives in Québec have also successfully developed a broad-based support for their movement over time that has rendered them influential players in the 


\section{Heneberry and Laforest (2011)}

political arena (Favreau, 2006). In Manitoba, mobilization was of consequence as well. The province developed a strong social economy and community economic development network that worked closely with the government. It is fair to say as well that timing in Manitoba was a factor in the promotion of cooperative support programs; the election of a NDP government with strong ties to the community created opportunities for the cooperative movement (Loxley \& Simpson, 2008). Both found synergies under the community economic development lens.

As the successful provincial examples all illustrate, by focusing on how participation and access is dispersed under new governance arrangements, we can gain a better understanding of how social relations between governments and cooperatives are ordered. The next section turns to the case of Ontario to retrace the history of how the relationship between the Ontario government and its cooperative sector has evolved.

\section{THE ONTARIO COOPERATIVE MOVEMENT}

The cooperative movement in Ontario has evolved over the past century from mostly an agricultural basis to become a broadly based series of organizations and cooperatives of different sizes, acting in a wide variety of policy areas, and providing a large array of services to members. As it stands, the largest number of co-ops (almost 45\%) operate in the nonprofit housing sector, followed by child care co-ops and financial services co-ops each representing $17 \%$, and agriculture the fourth largest single sector at $6 \%$. Cooperatives have also emerged in more recent years to respond to new needs of communities in areas of transportation, renewable energy, employment, and services for vulnerable populations (Ontario Co-operative Association, 2008a). These policy fields are still small, and as of 2007 collectively represented about 200 cooperatives, or only about $15 \%$, of the overall sector (Ontario Co-operative Association, 2008b).

The cooperative sector in Ontario is quite diverse and has been traditionally organized in silos, structured around these particular fields or areas of policy. In fact, the majority of the umbrella organizations representing the interests of cooperatives were organized along policy lines and dealt with industry specific issues that faced their cooperatively organized members. In keeping with the strong agricultural roots of the movement, the United Co-operatives of Ontario (UCO), the post WWII replacement of the United Farmers Co-operative Company, became the largest co-op in Ontario with both co-ops and individual farmers as members, and represented agricultural and farmer issues. Another example is the Ontario chapter of the Co-operative Housing Federation of Canada, which was formed in 1986 to represent the interests of cooperatives in the housing area (Co-operative Housing Federation of Canada website, 2011). In the area of credit unions, Central One, formerly known as the Credit Union Central of Ontario, and the Ontario Credit Union League before that, was formed in 1941 to represent the interests of credit unions and caisses populaires (Central One website, 2011).

On the policy front, cooperatives have traditionally mainly engaged directly with the Ministry grounded in their policy field, such as the Ministry of Municipal Affairs and Housing, or the Ministry of Child and Youth Services. In terms of resources for lobbying, each organization makes its decisions as to how important this activity is for their mandate and how much money they will put into supporting it. Therefore, certain parts of the cooperative sector, such as housing and agriculture, have stronger ties with government departments and more experience in lobbying than others.

It was only in the late 1940s, that an umbrella cooperative organization was finally formed to provide an associative function at a wider provincial level across a variety of policy fields. The existence of an Ontario based provincial level association has its roots in the 1946 founding of the Co-operative Union of Ontario, which 


\section{Heneberry and Laforest (2011)}

was a member of the national Co-operative Union of Canada (CUC). The Co-operative Union of Ontario eventually transitioned into the Ontario Co-operative Development Association (OCDA) in the 1960s, representing approximately $75 \%$ of the cooperatives in Ontario and providing educational, promotional, and development services to the movement (Select Committee on Company Law, 1971). The organization eventually transitioned to one that was a chapter of the national cooperative association, the Canadian Cooperative Association (CCA) [6]. CCA created a series of provincial chapters, including CCA Ontario in 1989, which had a focus on carrying out education on cooperatives in the school system.

\section{THE ONTARIO GOVERNMENT AND THE COOPERATIVE MOVEMENT: FORMALIZING THE RELATIONSHIP}

As the cooperative movement expanded into the 1960s and 1970s, the government of Ontario sought to better understand and support cooperatives from a legislative perspective. It created a Select Committee on Company Law to examine the state of the cooperative sector and identify its contribution to the Ontario economy. The Committee's final report, known as the Select Committee on Company Law Report on Co-operatives, examined the history of the cooperative movement's growth in Ontario and the factors that had contributed to the movement's expansion to date. The report concluded that the cooperative movement had developed more slowly in Ontario than in other provinces because there had not been the same level of provincial government support as in other provinces (Select Committee on Company Law, 1971). Indeed, other provincial governments had already seen the value in supporting their cooperative movement as a way to achieve relief from the economic downturns seen in the 1920s and 1930s (MacPherson, 2009). The report is significant because it recognized for the first time the necessary role of the Ontario government in supporting the growth of the movement, both from the perspective of providing legislative recognition, as well as providing more active support of the movement.

In 1974, the government of Ontario acted on the recommendations made in the final report of the Select Committee on Company Law Report on Co-operatives and adopted the Co-operative Corporations Act and the Credit Unions and Caisses Populaires Act which would enshrine the cooperative principles and character in Ontario legislation. The establishment of the Co-operative Corporations Act was a key marker that separated cooperatives out from other business models. It defined the "cooperative basis" on which enterprises needed to operate in order to be considered legitimate cooperative enterprises, and provided particular mechanisms related to the financial operations of cooperatives that were appropriate to their structure, including a unique regime for raising securities for cooperatives.

With the passing of this new legislation, cooperatives and credit unions became regulated by a single newly created cooperatives and credit union branch at the Ministry of Commercial and Consumer Affairs. This Ministry became their principal access point within the bureaucratic institution if there were specific issues that came up vis-à-vis the Acts. Sub-sectoral peak associations assured representation before government. The cooperatives mainly used their personal ties to bring about legislative change. The rural agricultural cooperatives, for example, were quite proactive at the time because they had strong ties to their communities and their local Members of Provincial Parliament (MPPs). Through such personal ties, the cooperative movement was successful at getting the Ontario government to tweak the Co-operative Act. However, a sectoral approach to lobbying the state for regulatory change had not yet developed.

The CCA Ontario, which was the principal umbrella organization at the time, did not have a mandate to engage with the Ontario provincial government. Being a chapter of a national organization, CCA Ontario's main function was to represent the Ontario cooperative sector's interests in the national arena. In terms of its relationship to its 


\section{Heneberry and Laforest (2011)}

members, the CCA Ontario's mandate was essentially to provide direct technical assistance to existing or emerging cooperatives to ensure their success and survival.

In 1998, the Harris government transferred the registrar and regulatory functions for cooperatives and credit unions to the newly created Financial Services Commission of Ontario (FSCO), an arms-length agency of the Ministry of Finance. However, the Ministry of Finance would continue to maintain a role with the co-op movement by remaining responsible for dealing with legislative changes to the Co-operative Corporations Act. FSCO brought all of the financial regulators together and the cooperative sectoral work was parcelled down into the various areas. The staffing levels of those dealing with cooperatives diminished and there was no longer inhouse expertise on cooperatives (interview with Ontario civil servant, July 14, 2010). More importantly, this institutional restructuring created a level of separation between the cooperative movement and the provincial government because there was no longer a centralized and direct relationship through one institution. Representatives of FSCO and the Ministry of Finance began to meet with representatives of the non-financial cooperative sector on a quarterly basis to discuss both operational and policy concerns, including any proposed changes to the legislation. Any proposed changes to the Co-operative Corporations Act were now required to go through two levels of policy review: by policy staff at FSCO as well as at the Ministry of Finance. This slowed down the process of making any changes to the legislation.

This relationship between the cooperative movement and its regulator is unique - no other provincial association in Canada has this level of institutionalized access (Ontario Co-operative Association, 2010). The Ontario cooperative movement's unique access to the regulatory institution provided a way for it to interact with government officials and identify challenges or barriers in the legislative environment that could be changed to benefit the cooperative movement as a whole. However, policy discussions focused solely on regulatory capacity. The ability of cooperatives to use this access point to obtain resources and programs from the Ontario government to support cooperative development was limited.

Until then, cooperatives in Ontario had only been seeking simple and discrete regulatory or legislative changes, rather than pursuing broader changes such as modernization of the legislation or sweeping changes that focused around broader policy support for the movement. In effect, there was no structure or organization that could lobby for such a broad policy agenda. The only provincial umbrella organization at the time, CCA Ontario, was not structured or organized to lobby effectively in the name of a broader provincial sectoral agenda. As the provincial chapter of a national organization, national headquarters whose sole preoccupation was the harmonization of activities and practices of cooperative enterprises and movements across the country dictated its mandate. With the level of interaction between cooperatives in Ontario and the provincial government increasing since the adoption of the Acts, those within the CCA Ontario ranks increasingly felt that they needed to transition to a more autonomous structure in order to be able to focus more directly on provincial interests and on the Ontario arena. Similarly, many other provincial chapters of CCA, like British Columbia, felt the need to transition toward an independent provincial umbrella organization. It was in this context that the Ontario Cooperative Association (On Co-op) was created in 2002.

\section{On Co-op: Creating a provincial umbrella group for the cooperative movement}

The Ontario Co-operative Association (On Co-op) was specifically structured to serve as a provincially based cooperative umbrella organization, with the largest Ontario cooperatives and federations as its members. It currently represents either directly or indirectly approximately $85 \%$ of the cooperatives operating in Ontario [7]. On Co-op sought representation from each of the sub-sectors and was able to involve the large cooperatives. It 


\section{Heneberry and Laforest (2011)}

had representation from the housing federation, the worker co-op federation, and the credit union sector. The francophone sector, whose representation is assured by the Conseil de la coopération de l'Ontario (CCO), was not at the table but over time On Co-op and its francophone counterpart, CCO, did collaborate on some files. Although there are numerous provincial organizations representing many sub-sectors of cooperatives, each with its own agenda, the creation of On Co-op was important for the cooperative movement as a whole because it led to the development of a systematic and strategic sectoral agenda.

While the cooperative movement is larger than On Co-op, the creation of this autonomous provincial umbrella organization is important because it represents an important formalization of the advocacy function of the cooperative sector at the provincial level, backed by resources dedicated specifically to it. The broader mandate of On Co-op made it possible for the organization to focus on building a coherent cooperative movement in Ontario. The mandate encompasses four main strategic directions: Membership and Communications, Education (referred to as Lifelong Co-operative Learning), Government Relations, and Co-operative Development. Of these four directions, two involve working to develop more awareness and support of the cooperative movement with a wide variety of audiences, including the general public, thus maintaining and growing the movement. The Co-operative Development arm of the organization involves promoting the cooperative model generally, and delivering services and programs to support existing cooperatives and develop new co-op enterprises. The Government Relations component of On Co-op involves representing and promoting the movement specifically to government, as well as educating government representatives in order to gain recognition of the movement and garner additional support for the movement.

Through its Government Relations work, On Co-op quickly became the formalized voice of the sector, particularly at the regulatory table. Although the actual representation of organizations regularly meeting with FSCO did not change, this representation was formalized into a working committee supported by and responsible to On Co-op.

\section{Articulating a Sectoral Agenda}

To develop a sectoral agenda for the cooperative movement in Ontario, On Co-op was influenced by the more successful government-cooperative relationships in other provinces. Where bureaucratic support for the cooperative movement beyond legislative or regulatory function was instituted, experience showed that cooperatives had obtained better support for their movement's activities. In particular, the province of Québec, with its internal department devoted to cooperatives, Direction des Coopératives that was part of the provincial Ministry of Economic Development, Innovation, and Export, served as a model. The Québec cooperative movement had lobbied their provincial government for many years which had led to the development of a formal partnership agreement between the Québec cooperative movement and the Québec government, providing the movement with funding and policy support (Ministère du Développement économique, de I'Innovation et de I'Exportation 2010). In order to learn from the Québec experience, On Co-op met with the Conseil québécois de la cooperation, and it was very inspired by the consultation process that had been launched in Québec.

Inspired by the Québec experience, On Co-op created a task force called the Task Force for Ontario Opportunities through Co-operative Development to explore the development needs of Ontario cooperatives. The task force received 27 written submissions and held seven regional meetings throughout Ontario (London, Sudbury, Kingston, Thunder Bay, Kitchener, Ottawa, and Mississauga). The regional meetings focused on gathering input from both individual cooperatives as well as the sectoral cooperative associations or federations that represented their interests (such as Credit Union Central of Ontario and the Ontario Worker Co-operative 


\section{Heneberry and Laforest (2011)}

Federation). These regional meetings provided an impetus for cooperatives from a variety of policy areas to come together and discuss their common interests.

This was a key turning point for the cooperative movement. Until then, most lobbying had been articulated around particular policy or industry lines such as housing, childcare, agriculture, etc. Many cooperatives interviewed referred to this consultation process as the start of a shift that helped the cooperative movement become more strategic in terms of their demands to government. By gathering and synthesizing a set of common viewpoints from a diverse set of cooperative organizations, the task force was able to prioritize sectoral demands and generate awareness around the sectoral needs. The consultation process culminated in the creation of a report entitled "Capturing Co-operative Opportunities: A White Paper for Co-operative Development" also known as the "White Paper" (Ontario Co-operative Association, 2005), which would become the jumping off point for the strategy of the movement as a whole. As one of our interviewees stated:

I think the paper ended up being the basis for the motivation for a lot of meetings we had with the MPPs and with the party conferences, bureaucrats. ... Basically, that's what our main activity over the last few years [has been] following up on that. But I think there's been a positive offshoot to that, which is that it's really created a framework within which On Co-op has lobbied government. (August 20, 2011)

The "White Paper" became a catalyst to move the relationship between government and the cooperative movement forward. It also represents the earliest cohesive articulation of demands for active development support. The report identified areas of action for both the cooperative movement and the provincial government that would result in growth and positive developments for cooperatives across the province. The key action identified for the provincial government as a result of this process was the creation of a Provincial Co-operatives Secretariat that would act as a single voice for the co-op sector within government. This body would be an important institution that would assist in creating further avenues for active co-op development support and support the development of a more appropriate regulatory regime for Ontario cooperatives. To this day, it remains an important sectoral demand.

On Co-op was well aware that it could not move its policy agenda forward without political allies to champion it to the provincial government. In parallel to the Task force consultations, On Co-op staff and volunteers met with a number of MPPs to raise awareness of the cooperative model and draw attention to the need to develop a framework to strengthen the relationship between the cooperative movement and the government in Ontario. They met with MPPs representing over 30 Ontario electoral ridings. In addition, roundtable discussions were held at Queen's Park with MPPs and other government staff in November 2004.

Although On Co-op met with less than one third of the ridings in Ontario, the time and effort needed to schedule and attend these meetings was significant for On Co-op. In 2004, there was no full-time staff member in place supporting government relations efforts, and so On Co-op's Executive Director and its Government Relations Committee, made up largely of volunteers, undertook these lobbying efforts. Part-time consultants supplemented their work when funds became available. This approach would prove strenuous in the long term.

Building on the momentum that had developed through the White Paper process and on the alliances they had forged with MPPs, On Co-op scheduled another round of 14 meetings with MPPs in late 2005 through to 2006. These meetings were an opportunity to provide MPPs with the outcomes of the White Paper process and generate support for the resulting recommendations that had been developed, primarily pushing for the development of a Provincial Co-operatives Secretariat. Eventually, the cooperative movement found an ally in 


\section{Heneberry and Laforest (2011)}

Ted McMeekin, Liberal MPP for Ancaster-Dundas-Flamborough-Aldershot, who took up the cause. After a series of meetings with On Co-op and members of the Government Relations Committee, MPP McMeekin tabled a resolution in the Ontario Legislature on December 14, 2006:

That, in the opinion of this House, the Government of Ontario should commit to the promotion, development and support of the co-operative model of business as one that should be replicated to provide stronger communities, increased social responsibility and continued economic growth. That the Ministry of Economic Development and Trade commit to investigating the establishment of a Co-operatives Secretariat to support the co-operative model of business. (Ontario Cooperative Association, 2008a, p. 2)

The cooperative movement's lobbying efforts had produced a positive result. Thanks to McMeekin's championship and to the groundwork that had been done between 2004 and 2006, the resolution passed. The movement was now tasked with moving beyond the step of generating awareness and a gentle commitment to investigate, toward transforming this political will into action and realizing these goals.

Timing would prove to be a challenge, however. Shortly after the resolution was passed, the province of Ontario found itself gearing up to enter into the 2007 election campaign. On Co-op created a Co-op Advocates program to enable members, staff, and directors of cooperatives to approach political candidates during the 2007 preelection campaign to ask them for support for the development of the Co-operatives Secretariat or to support cooperatives more generally. It was the hope to have at least one identified advocate in every electoral riding in the province that could be called upon to attend meetings with MPPs. In an effort to relieve the pressure on On Co-op staff that had invested so much time and energy lobbying MPPs from 2004 and 2006, it ran the Co-op Advocated program on a volunteer basis and asked for in-kind contributions from its member organizations. However, the amount of work needed to co-ordinate this process on the part of On Co-op staff was intensive. They approached an estimated 600 people over the course of 2007 to be potential advocates; only about 10 people were willing to do it. The burden imposed on volunteers was too high and many of those contacted were not comfortable with that advocacy role.

Not only did their advocacy strategy prove unsuccessful, the Liberal Party of Ontario won the election and on October 30, 2007, their main political champion, MPP Ted McMeekin, became Minister of Government and Consumer Services. In his new role as Minister, the cooperative movement naturally lost a certain access to him because of his new responsibilities. Although he continued to believe in the cooperative model, it also became more difficult for McMeekin, in his new functions as Minister, to continue to champion for a particular sector, at the expense of others. Hence, all of the efforts that had been invested by the cooperative movement toward developing a champion for their cause had evaporated. As a result, On Co-op decided to reorient their strategy and focus on building allies within the bureaucratic apparatus.

\section{Shifting gears: Seeking allies within the bureaucracy}

A new strategy focusing more squarely on the bureaucratic state had the benefit of opening a relationship between government and the cooperative movement that had not been utilized to date. The 2006 resolution had targeted the Ministry of Economic Development and Trade (MEDT) as the key ministry to investigate the Secretariat, because of its focus on broader economic development in a variety of policy and business areas. Movement representatives attempted to schedule several meetings with MEDT staff, including additional meetings with political staff and Minister Sandra Pupetello herself, with the help of MPP Ted McMeekin. 


\section{Heneberry and Laforest (2011)}

Between 2007 and 2010, movement representatives met ten times with MEDT, primarily with bureaucratic staff, with no positive results toward the creation of the Secretariat. Numerous cabinet shuffles over this period of time had made it difficult to build any sustainable relationship with the MEDT. The cooperative movement was a newcomer to this policy portfolio and so they did not have a long history of ties and interaction with the MEDT that they could count on in this period of high turnover. It also became clear relatively quickly that there was not a strong appetite at MEDT to create a provincial Secretariat.

Movement representatives had been told by civil servants in the MEDT over 2008 and 2009 that the likelihood of the government funding an initiative like the Secretariat was highly unlikely due to the economic crisis facing Canada and Ontario (interview with cooperative organizations, February - August, 2011). Instead, they suggested that the cooperative movement focus on shorter-term and less financially intensive goals that would be considered more achievable and easier to support by the government.

Frustration began to mount within the cooperative movement. A lot of time and effort had gone into creating strategies and attempting to gain access to the Ministry in order to push the goal of the Secretariat forward, only to be told that something different had to be proposed. This turn of events forced On Co-op to re-examine the direction and goals of the movement related to the Provincial Co-operatives Secretariat. In response, On Co-op created a new "wish-list" of 13 discrete items that ranged from requests to have the government deal with outstanding requests for amendments to the Co-operative Corporations Act, to the consideration of tax incentives that were more favourable to cooperatives, to educational and development materials for cooperative development to be placed in Small Business Enterprise Centres and training sessions for the staff of these centres to better equip them to assist start-up cooperatives.

Although many of these items were similar to the original recommendations that had been published in the original White Paper, the process that had led to the establishment of this wish list was radically different. For one, it did not involve movement-wide consultation, nor did all of the original individuals and organizations involved with the White Paper consultations vet the wish list. Rather, the On Co-op staff and the Government Relations Committee wrote it. At that point, On Co-op was faced with having to interact with the government on a much tighter schedule and produce materials and positions more quickly or with much less notice than a fullfledged consultation process would have easily permitted. Although a more expedient approach, this was a missed opportunity to reconnect with the original actors that had participated in the creation of the "White Paper" report and have them commit to the new direction in which On Co-op was headed.

The 13-point wish list was eventually cut down even further into a six-point list, at the request of MEDT staff, to further prioritize discrete activities that could be handled by government in relatively short order. The strategic choice was driven to some extent by recognition of the need to further open the political institution of MEDT, and cultivate allies and elites within that structure, before being able to demand the larger policy goal of a provincial body like the Secretariat. For two of the organizations we interviewed, however, the reduction of the demands represents a move backwards for the cooperative movement as a whole (June 8, 2010). Instead of being framed around one overarching structure or vision of partnership with the state that would bring positive change for the entire cooperative movement, the demands were instead broken down into a series of smaller insular recommendations that could be worked on individually by government. Despite all of the time and effort invested in generating awareness with respect to active development support programs, it appears that the cooperative movement fell short. 


\section{Heneberry and Laforest (2011)}

\section{CONCLUSIONS: LESSONS LEARNED}

Government support of the cooperative movement can take several different forms, with active cooperative development support potentially being the most important to the movement in terms of its ability to grow. Several provincial governments across Canada have seen the potential for beneficial policy outcomes by supporting the cooperative movement in their province and recognized its social and economic contributions to its members and the communities in which the co-ops operate, including the ability to create and maintain employment and provide needed services to a wide range of audiences and populations. In particular, the governments of Newfoundland and Labrador, Manitoba, and most notably Québec, have entered into agreements with their respective cooperative sectors to provide active cooperative development support. Not surprisingly, the Ontario movement, being one of the country's largest, inspired by both active development support provided or offered at the federal level, and by what was happening in other provinces, sought to obtain similar support for itself from its provincial government.

It seems clear that the Ontario cooperative movement has made some positive strides in mobilizing itself to work with government, by raising awareness about the positive contributions that cooperative enterprises make among a number of different government institutions and representatives. However, the movement still faces some challenges in cultivating allies inside the needed political institutions that can be used to effectively advance its goals. Despite all of the time, resources, and energy involved, the relationships that the cooperative movement has been working to develop and maintain have not resulted in more open access to the political system. Two potential explanations could be offered in light of other provincial experiences.

For one, the Ontario cooperative movement, like that of many other provinces, has a weak tradition of lobbying the provincial government in the name of the "sector." According to Fulton and Laycock (1990, p. 142), cooperatives have "a disinclination to become involved in broad-ranging public policy discussions and an opposition to expansion of state enterprise except where this directly promotes cooperatives' institutional interests." In that sense, the Ontario cooperative movement faced the double barrier of having to convince cooperatives to look beyond their institutional interests and think in terms of sectoral interests; and the barrier of actually having to lobby in the name of those interests.

The "White Paper" process itself was the first example of the movement coming together at a broader sectoral level rather than on a policy field basis. These opportunities allow for different parts of the movement to come together and see how the common values and principles of co-operation are demonstrated in different types of co-ops, which can contribute to the building of a cooperative identity in which all co-ops see their organization reflected. However, what has been missing is the next step of attaching these networking and learning opportunities to a larger identity for the movement that impacts positively on how the stated advocacy outcomes for the movement will benefit their own organizations, i.e., that co-ops and co-op organizations see value in the requests being made of government, and therefore contribute time and effort to support them. The Québec cooperative movement has a stronger tradition of mobilization and cooperatives are politically engaged. This in part explains its ability to maintain strength in the movement over time.

The "White Paper" process demonstrated that the movement could mobilize on a broad scale, across policy areas, and participate in a movement-wide identity building effort. However, since that time, the cooperative movement has not come back together at the same scale to revisit these earlier identity building activities and confirm interest in the direction of the movement with regard to the creation of the Secretariat or any of the other demands that have been placed before the provincial government. It would behoove the movement to circle back on a broader scale to attempt to establish or re-establish the importance of creating active cooperative 


\section{Heneberry and Laforest (2011)}

development support for the movement, either in the form of the Provincial Co-operatives Secretariat or in the form of the other recommendations that were originally identified.

The second challenge has been the volatile nature of the political environment in Ontario, which at times undermined some of the advances that had been made by the cooperative movement. This volatile context made it difficult for cooperative organizations to maintain their momentum and to build a sustainable relationship with the provincial government. For example, a lot of time was invested in a strategy that focused on the MPPs and the political arm of government. While the biggest success of the movement was without a doubt the passing of the special motion in the Ontario legislature, an election followed shortly after which meant that the political environment shifted again.

Similarly, the cooperative movement made great gains when the Ministry of Economic Development and Trade became the main point of contact for the sector within government. In many of the cases where a strong relationship had developed between provincial governments and cooperatives, an institutional arrangement that would give cooperatives a point of access to make their claims seemed to be a key factor of success (Fairbairn, 2000a, 2000b). However, in the case of Ontario, the high turnover within the bureaucracy meant that any progress made on convincing bureaucrats that cooperatives could be a valuable source of economic and social development, and therefore should be supported, was short-lived. This limited the ability of the cooperative movement to make headway on its demand to government with respect to the creation of a Provincial Cooperatives Secretariat, or for any sort of meaningful active cooperative development support for that matter. Although the movement has adjusted its strategies recently to make demands that are smaller in scope and impact but that would still be considered to engage the government in more active support, its strategy has not yet produced results. It is unclear at what point institutional access will be open enough again for the movement to re-focus its demands on the development of the Secretariat and its broader sectoral agenda. However, the cooperative sector has taken the first steps by giving itself an infrastructure body where these discussions can take place, and where communication and collaboration can develop within the sector.

\section{ACKNOWLEDGMENTS}

The authors wish to thank all the organizations that participated in this research and provided access to their document library and materials. We would also like to thank Peter Elson and the anonymous reviewers for their helpful suggestions.

\section{NOTES}

1. Cooperatives can be defined as "an autonomous association of persons united voluntarily to meet their common economic, social, and cultural needs and aspirations through a jointly owned and democratically controlled enterprise" (International Co-operative Alliance (ICA, 2011). They generally embrace a set of principles and values as outlined in the ICA's co-operative identity statement.

2. As of 2007, the sector in Ontario was comprised of approximately 1,300 co-ops, with over 1.4 million Ontarians being co-op members, and had an asset base of $\$ 30$ billion dollars (Ontario Co-operative Association $2008 \mathrm{~b}$.

3. The organizations interviewed were the Ontario Co-operative Association, the Agency for Co-operative Housing, the Co-operative Housing Federation of Canada - Ontario Region, the Co-operators, GROWMARK, the Canadian Co-operative Association, and Iler Campbell. We conducted multiple interviews with staff members in the organizations that were most involved in the advocacy work.

4. The majority of cooperatives are incorporated and governed at the provincial level. Although there is federal legislation that governs cooperatives that have operations in more than one province, the Canada Cooperatives Act, the number of cooperatives that are incorporated and operating under that Act are relatively small. 


\section{Heneberry and Laforest (2011)}

5. Québec's cooperative movement is the largest in the country with the most number of cooperatives and the highest economic contribution in terms of sales and assets. According to 2007 statistics, Québec boasts 3,300 co-ops and mutual insurance companies, of which 2,666 are not financial. Together, Quebec co-ops have assets of $\$ 130$ billion and sales totalling $\$ 30$ billion (Rural and Cooperatives Secretariat, 2010; see also Simard, n.d.).

6. Canadian Co-operative Association is the successor to the original national Anglophone co-op association, the Co-operative Union of Canada (CUC). CCA was formed in 1987 when the CUC, which had been focused primarily on lobbying and international development activities, merged with the Co-operative College of Canada, which was a national educational body (CCA, 2008).

7. On Co-op's membership is made up of associations or federations of cooperatives (such as GROWMARK, Inc., OPPCEO, the Cooperative Housing Federation of Canada, Ontario Student Co-operative Housing Association, and the Canadian Worker Co-operative Federation) or credit unions (Central 1 Credit Union and Credit Union Central of Canada).

\section{REFERENCES}

Agranoff, R. (2006). Insider collaborative networks: Ten lessons for public managers. Public Administration Review, 66(1), 56-65.

Bryson, J. M., Crosby, B.C., \& Stone, M.M. (2006). The design and implementation of cross-sector collaborations: Propositions from the literature. Public Administration Review, 66, 44-55.

Canadian Co-operative Association (2008). Provincial and sectoral profiles. URL: http://www.coopscanada.coop/assets/firefly /files/files/pdfs/ProvAndSectoralProfiles/ [February 22, 2011].

Casey, J., \& Dalton, B. (2006). The best of times, the worst of times. Australian Journal of Political Science 41(1), 23-38.

Casey, J., Dalton, B., Melville, R., \& Onyx, J. (2010). Regulating government-community sector relations: International experiences with compacts. Voluntary Sector Review, 1(1), 59-76.

Central One. (2011). Home. URL: http://www.central1.com [November 23, 2011].

Co-operative Housing Federation of Canada. (2011). Home. URL: http://www.chfc.ca/index.asp [November 23, 2011].

Elson, P. (2006). Tracking the implementation of voluntary sector-government policy agreements: Is the voluntary and community sector in the frame? International Journal of Not-for-Profit Law, 8(4), (pp. 34-49).

Fairbairn, B. (2000a). Co-operative development and the state: Case studies and analysis. Part 1: Summary, observations, and conclusions about co-operative development. Saskatoon, SK: Centre for the Studies of Co-operatives.

Fairbairn, B. (2000b). Co-operative development and the state: Case studies and analysis. Part 2: Issues in co-operative development and co-operative-state relations. Saskatoon, SK: Centre for the Studies of Co-operatives.

Favreau, L. (2006). Social Economy and Public Policy: The Quebec Experience. Horizons, 8(2), 7-15.

Fulton, M., \& D. Laycock. (1990). Co-operatives and government. In M. Fulton (Ed). Co-operative organizations and Canadian society: Popular institutions and the dilemmas of change (pp. 141-160). Toronto: University of Toronto Press.

Government of Québec (2003). Politique de développement des coopératives: Horizon 2005. Quebec: Government of Quebec.

Guy, D., \& Heneberry, J. (2009). Building bridges with government: The social economy in practice. In J.J. McMurtry (Ed.) Living Economics (pp. 217-267). Toronto, Canada: Edmond Montgomery Press.

Howlett, M. (2000). Managing the "hollow state": Procedural policy instruments and modern governance. Canadian Public Administration, 43, 412-431.

International Co-operative Alliance (ICA). (2011). Home. URL: http://www.ica.coop/al-ica [November 23, 2011]. 


\section{Heneberry and Laforest (2011)}

Kostyra, E. (2006). Made in Manitoba: Community economic development: Provincial policy framework and lens. Horizons, 8(2), 2224.

Laforest, R. (2007). The politics of state-civil society relations in Quebec, In M. Murphy (Ed.) Canada: The State of the Federation 2005. Quebec and Canada in the New Century: New Dynamics, New Opportunities (pp. 177-198). Montreal: McGill-Queen's University Press.

Laforest, R. (2011). Voluntary sector organizations and the state. Vancouver: UBC Press.

Laforest, R. \& Phillips, S. (2001). Repenser les relations entre le gouvernement et le secteur bénévole: À la croisée des chemins au Québec et au Canada. Politique et Sociétés, 20(2-3), 37-68.

Laycock, D. (1987). Co-operative-government relations in Canada: Lobbying, public policy development and the changing cooperative system. Saskatoon: Centre for the Study of Co-operatives, University of Saskatchewan.

Loxley, J., \& Simpson, D. (2008). Government policies towards community economic development and the social economy in Quebec and Manitoba. Paper produced as part of the Research Reports Series, Social Economy project, Prairie Hub.

MacPherson, I. (1979). Each for all: A history of the co-operative movement in English Canada, 1900-1945. Toronto, ON: Macmillan, The Carleton Library.

MacPherson, I. (2009). A Century of co-operation. Ottawa, ON: Canadian Co-operative Association.

Ministère du Développement économique, de l'Innovation et de l'Exportation. (2010). Support for cooperative development from Ministère du Développement économique, de I'Innovation et de l'Exportation du Québec (Orientations and Results). Quebec: Gouvernement du Québec.

Newman, J. (2001). Modernising governance: New labour, policy and society. London: Sage.

Ontario Co-operative Association. (2005). Capturing co-operative opportunities: A white paper for co-operative development in Ontario. URL: http://www.ontario.coop/cms/documents/119/2005 GR On_Co-op_White_Paper.pdf [December 12, 2010].

Ontario Co-operative Association. (2008a). The 2007 Ontario co-operatives \& credit union census. URL: http://www.ontario.coop/ cms/documents/202/2008-04 CENSUS Overview.pdf [December 12, 2010].

Ontario Co-operative Association. (2008b). Shaping a provincial co-operatives secretariat: Providing innovative and sustainable solutions to build a better and stronger Ontario. URL: http:// www.ontario.coop/cms/documents/191/GR Provincial_Co-op_Secretariat_Proposal.pdf [December 12, 2010].

Ontario Co-operative Association. (2010). Provincial support for co-operative sector: A comparative snapshot across Canada. Toronto, ON: Government of Ontario.

Ontario Co-operative Association. (2010). Accomplished MPP \& ministry meetings (since 2006). URL: http://www.ontario.coop/cms Idocuments/208/GR Accomplished Gov t Meetings.xls [December 18, 2010].

Peters, B. Guy (2001). The future of governing. Lawrence: University Press of Kansas.

Phillips, S. (2003). Voluntary sector-government relationships in transition: Learning from international experience for the Canadian context. In K. L. Brock \& K. G. Banting (Eds.) The nonprofit sector in interesting times: case studies in a changing sector (pp. 17-70). Montreal-Kingston, Canada: McGill-Queen's University Press.

Phillips, S. (2009). Canada's new government and the voluntary sector: Wither a policy agenda? In R. Laforest (Ed.) The Conservative Federal Policy Agenda and the Voluntary Sector: On the Cutting Edge (pp. 7-34). Montreal: McGill-Queen's University Press.

Quarter, J. (1992). Canada's social economy: Co-operatives, non-Profits, and other community enterprises. Toronto: James Lorimer. 


\section{Heneberry and Laforest (2011)}

Rhodes, R. (2000). Governance and public administration. In J. Pierre (Ed.), Debating Governance (pp. 54-90). Oxford: Oxford University Press.

Rural and Co-operatives Secretariat. (2010). Co-operatives in Canada (2007 Data). Ottawa, ON: Government of Canada: Ottawa.

Salamon, L. (2002). The new governance and the tools of public action: An introduction. In L. Salamon (Ed.), The Tools of Government: A Guide to the New Governance (pp. 1-47). New York, NY: Oxford University Press.

Select Committee on Company Law. (1971). Report of co-operatives, 4th Session, 28th Legislature. Ottawa, ON: Government of Canada.

Simard, H. (n.d.). The cooperative movement of Quebec: A dynamic and diversified movement. URL: http://www.ace.coop/portals 10/institute/04/simard.pdf [February 22, 2011].

Smith, R. E. (2010). The relationship between Saskatchewan's co-operative community clinics and the Government of Saskatchewan: Toward a new understanding. Thesis. University of Saskatchewan: College of Graduate Studies and Research.

Stoker, G. (1998). Governance as theory: Five propositions. International Social Science Journal, 155, 17-28.

Toftisova, R. (2005). Implementation of NGO-government cooperation policy documents: Lessons learned. International Journal of Not-for-Profit Law, 8(1), 11-41.

\section{About the authors / Les auteurs}

Jen Henberry is a graduate student of Queen's University, School of Policy Studies MPA program. Email: ien.heneberry@gmail.com

Rachel Laforest is Associate Professor at the School of Policy Studies, Queen's University. Email: laforest@queensu.ca 